\title{
PEMBERIAN SUPLEMEN JAHE MERAH DAN SENAM KAKI DIABETIK BAGI JAMAAH MASJID ALAM SEMESTA (MAS) SEMPAJA SAMARINDA
}

DOI: https://doi.org/10.33024/jkpm.v4i5.4310

\author{
Mayusef Sukmana ${ }^{1 *}$, Ida Ayu Kade Sri Widiastuti ${ }^{2}$, Endang Sawitri ${ }^{3}$, Nurul \\ Hasanah $^{4}$, Muhammad Aminuddin ${ }^{5}$, Iwan Samsugito ${ }^{6}$, Anik Puji Rahayu ${ }^{7}$ \\ Azi Surya Kurniawan ${ }^{8}$, Yoga Bowo Leksono9, Syaiful Yanwar ${ }^{10}$ \\ 1,2,3,4,5,6,7 Dosen Fakultas Kedokteran Universitas Mulawarman \\ ${ }^{8,9,10}$ Mahasiswa Prodi D3 Keperawatan Fakultas Kedokteran Universitas \\ Mulawarman
}

Disubmit: 30 April 2021 Diterima: 05 Mei $2021 \quad$ Diterbitkan: 01 Oktober 2021

*Email korespondensi: 200801sukmana@gmail.com

\begin{abstract}
ABSTRAK
Pelaksanaan kegiatan ibadah di masjid memiliki risiko terjadinya penularan covid-19. Upaya yang dilakukan mencegah penularan selain menerapkan protokol kesehatan adalah dengan meningkatkan imunitas dan meningkatkan kebugaran jamaah masjid melalui pemberian jahe dan senam kaki diabetic. Pengabdian masyarakat bertujuan jamaah masjid Alam Semesta Sempaja Samarinda mampu mempraktikan senam kaki diabetik dan meminum jahe dalam rangka meningkatkan kebugaran dan imunitas tubuh. Metode yang digunakan adalah mendemontrasikan senam kaki diabetic, senam bersama, edukasi manfaat jahe, meminum jahe bersama dan membagikan jahe untuk 7 hari. Kegiatan menerapkan protokol kesehatan melalui pengukuran suhu dan membagikan masker, Kegiatan dikuti oleh seluruh jamaah Masjid Alam Semesta Sempaja berjumlah 80 orang. Para jamaah mampu melakukan senam kaki diabetic dan rutin meminum jahe.
\end{abstract}

Kata kunci : Senam Kaki Diabetic, Jahe

\section{ABSTRACT}

The implementation of worship activities in mosques has a risk of covid-19 transmission. Efforts made to prevent transmission in addition to implementing health protocols are to increase immunity and improve the fitness of mosque's congregations through the provision of ginger water and diabetic foot exercises. Community service aims at the congregation of the Alam Semesta Sempaja Samarinda mosque to be able to practice diabetic foot exercises and drink ginger water in order to improve fitness and immunity. The method used was to demonstrate diabetic foot exercise, doing the exercise together, educate the benefits of ginger water, drink ginger water together and distribute ginger water for 7 days. The activity of implementing health protocols by measuring temperature and distributing masks, this activity was attended by 80 congregations of the Alam Semesta Sempaja Mosque. The congregation is able to do diabetic foot exercises and drink ginger water regularly.

Keyword: Diabetic Foot Gymnastics, Ginger Water 


\section{PENDAHULUAN}

Covid-19 merupakan penyakit yang telah menjadi darurat kesehatan global(Sukmana, Aminuddin, \& Nopriyanto, 2020), berdampak pada semua aspek kehidupan. (WHO, 2020) Pemerintah melakukan pembatasan pada hampir semua bidang kegiatan dalam rangka pencegahan penularan yang lebih masif melalui kebijakan Pembatasan Sosial Berskala Besar(PSBB)(Kemenkes RI, 2020). Aspek yang terpenting kehidupan sehari-hari adalah dalam kegiatan keagamaan(Asep Shodiqin, Rohmanur Aziz, Ratna Dewi, 2019). Pembatasan kegiatan keagamaan diantaranya menghimbau tidak sholat berjamaah di Masjid bagi daerah yang berzona merah(Kemenkes RI, 2020). Rumah ibadah termasuk masjid merupakan salah satu tempat yang dibatasi karena dianggap sebagai tempat yang memiliki risiko tinggi terjadinya penularan(Texas Medical Association, 2020). Risiko akan semakin tinggi jika jumlah orang yang berkumpul dalam satu waktu cukup lama dan banyak dengan ventilasi yang tidak memadai. Peningkatan jamaah terjadi khususnya pada sholat jum'at. Pada aturan PSBB konsentrasi masyarakat pada satu tempat paling banyak adalah 5 orang dangan tetap menjaga jarak. Karakteristik berdasarkan usia jamaah adalah lebih dari usia 40 tahun dimana usia menjadi salah satu faktor risiko penularan.

Pandangan berbeda terjadi dikalangan para ulama bahwa untuk mencegah penularan maka sesungguhnya risiko penularan dapat dikelola dan dikendalikan dengan menggunakan masker, mencuci tangan, dan menjaga jarak (Asep Shodiqin, Rohmanur Aziz, Ratna Dewi, 2019)(Theopilus, Yogasara, Theresia, \& Octavia, 2020). Pemahaman ini menjadi alasan mengapa masjid sebaiknya tetap dibuka. Pembukaan masjid dilakukan dengan menggunakan protokol kesehatan yang ketat dapat mengendalikan risiko penularan. Masjid Alam Semesta salah satu yang tetap melaksanakan kegiatan sholat berjamaah 5 waktu dan sholat jum'at.

Penerapan protokol yang kesehatan di Masjid harus diperkuat dengan upaya lain agar risiko penularan covid-19 dapat diminimalisir sehingga menghindari terbentuknya kluster baru di masjid. Selain penerapan protokol kesehatan salah satu pencegahan penularan adalah dengan meningkatkan imunitas dan meningkatkan kebugaran tubuh. (Amalia, Irwan, \& Hiola, 2020)

Imunitas dipengaruhi oleh asupan makanan, makanan yang bervariasi mengandung unsur karbohidrat, protein, lemak dan mineral dengan jumlah yang cukup diharapkan dapat meningkatkan imunitas tubuh. Dalam kondisi masukan yang tidak adekuat suplemen menjadi unsur yang penting melengkapi kebutuhan metabolisme tubuh. Suplemen yang diajurkan diantaranya adalah jahe(Tim Kerja Kementerian Dalam Negeri, 2020). Jahe memiliki sifat imunostimulator dan imunomodulator(Yuswanto Dyah; Sudarsono, Sudarsono \& Sudarsono Agustinus; Mellawati, Dyah, 2010)(Thineshini Devagaran \& Farmasi, 2012)(Biro kerjasama hukum dan humas LIPPI, 2020). Bentuk sajian konsumsi berupa minuman jahe(Saputri, Dania, \& Putranti, 2019). Jahe merah masuk dalam Riset herbal yang dilakukan oleh Lembaga Ilmu Pengetahuan Indonesia untuk penanganan COVID-19 sebagai imunomodulator(Biro kerjasama hukum dan humas LIPPI, 2020)

Pencegahan penularan selain meningkatkan sistem imun adalah dengan menjaga kebugaran tubuh. Berolah raga atau beraktivitas fisik yang teratur, terencana akan meningkatkan kebugaran dan fungsional tubuh(Prativi \& Artikel, 2013). Aktivitas fisik yang mudah dan praktis dilakukan di dalam masjid atau disekitar lingkungan masjid adalah senam kaki diabetik. Senam kaki diabetik dapat memperlancar aliran darah, gerakannya memperkuat otot kecil dan mencegah kelainan bentuk kaki serta meningkatkan kebugaran tubuh(P2PTM 
Kemenkes RI, 2019)(Mangiwa, Mario E. Katuk, \& Lando Sumarauw, 2017)(Flora \& Purwanto, 2014)

Masyarakat di wilayah Sempaja, khususnya jamaah masjid Alam Semesta Sempaja Samarinda, dari hasil studi pendahuluan rata-rata para jamaah berusia 45 tahun ke atas, sehingga memiliki risiko terjadinya penyakit degeneratif termasuk gangguan sirkulasi perifer pada ekstremitas bawah seperti neuropatik dan periperal arterial desease. Sehingga kegiatan yang meningkatkan sirkulasi pada daerah kaki perlu dilakukan secara teratur. Berolah raga atau beraktivitas fisik yang teratur, terencana akan meningkatkan kebugaran dan fungsional tubuh(Prativi \& Artikel, 2013). Aktivitas fisik yang mudah dan praktis dilakukan di dalam masjid atau disekitar lingkungan masjid adalah senam kaki diabetik. Senam kaki diabetik dapat memperlancar aliran darah, gerakannya memperkuat otot kecil dan mencegah kelainan bentuk kaki serta meningkatkan kebugaran tubuh(P2PTM Kemenkes RI, 2019)(Mangiwa et al., 2017)(Flora \& Purwanto, 2014)

Tujuan pengabdian masyarakat adalah para jamaah mampu melakukan senam kaki diabetic dan rutin meminum jahe dalama rangka meningkatkan imunitas jamaah masjid Alam Semesta Sempaja.

\section{MASALAH}

Alasan kami memilih lokasi di MAS adalah Jamaah masjid merupakan kelompok yang berisiko tinggi terjadinya penularan covid-19 karena kontak terjadi lebih dari 15 menit dan kegiatan sholat dilaksanakan secara berulang. Risiko penularan menjadi menurun dengan meningkatkan sistem imun tubuh melalui senam kaki dan minum jahe.

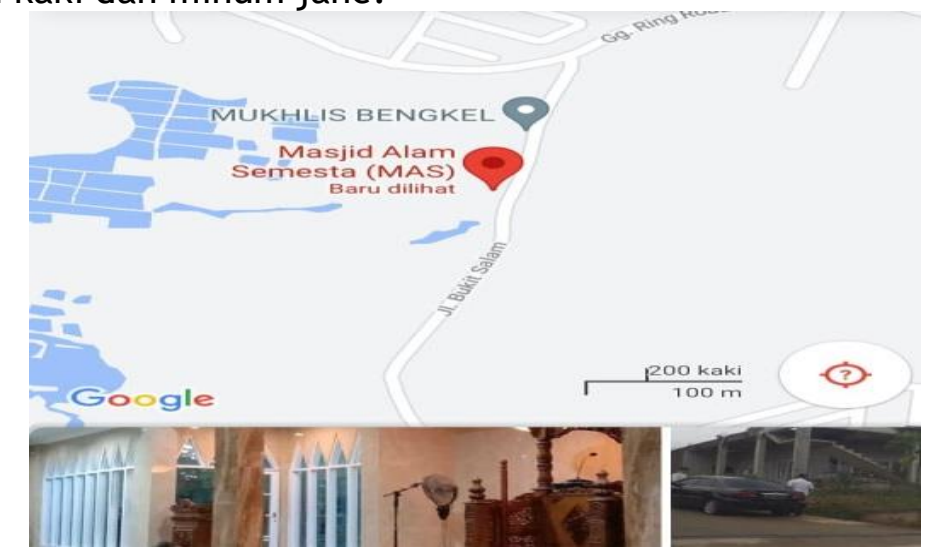

Gambar 2. 1. Peta lokasi kegiatan pengabdian masyarakat

\section{METODE}

Pengabdian masyarakat dilaksanakan pada tanggal 14 November 2020 dan 21 November 2020. Waktu kegiatan berlangsung pukul 05.30 sd 07.15 WITA. Sasaran pengabdian masyarakat adalah jamaah MAS di Sempaja Samarinda yang hadir berjumlah 80 orang.

\section{a. Tahap persiapan}

Tahap persiapan meliputi membuat preplanning kegiatan, menghubungi ketua masjid Alam Semesta Sempaja, membuat lefleat, pembelian produk jahe yang telah memiliki ijin edar.

b. Tahap pelaksanaan 
Proses berlangsungnya kegiatan pengabdian masyarakat sebagai berikut:

1) Penerapan protokol kesehatan(Kementerian Kesehatan Republik Indonesia, 2020): jamaah yang masuk ke masjid diukur suhu tubuhnya. Para jamaah memasuki masjid satu persatu.

2) Membagikan masker(Kementrian Kesehatan RI, 2020) jamaah yang masuk ke dalam masjid tidak menggunakan masker diberikan masker dan diminta untuk memakainya.

3) Memberikan pendidikan kesehatan manfaat senam kaki, mendemontrasikan senam kaki yang diikuti oleh seluruh jamaah (P2PTM Kemenkes RI, 2019). Selama kegiatan ini edukator dilaksanakan oleh Ns. Muhammad Aminuddin, S.Kep, M.Kep menyampaikan materi tentang konsep senam kaki diabetik kemudian mempraktekan dengan 2 (dua) cara duduk dilantai dan duduk menggunakan kursi. Para jamaah sangat antusias dalam mengikuti materi penyuluhan dan mempraktekan langsung dengan mengikuti gerakan yang dicontohkan oleh edukator.

Gerakan Senam Kaki Diabetik i(link video https://youtu.be/5tQlQGwuqNw

i. $\quad$ Duduk di lantai atau duduk tegak diatas bangku dengan kaki menyentuh lantai.

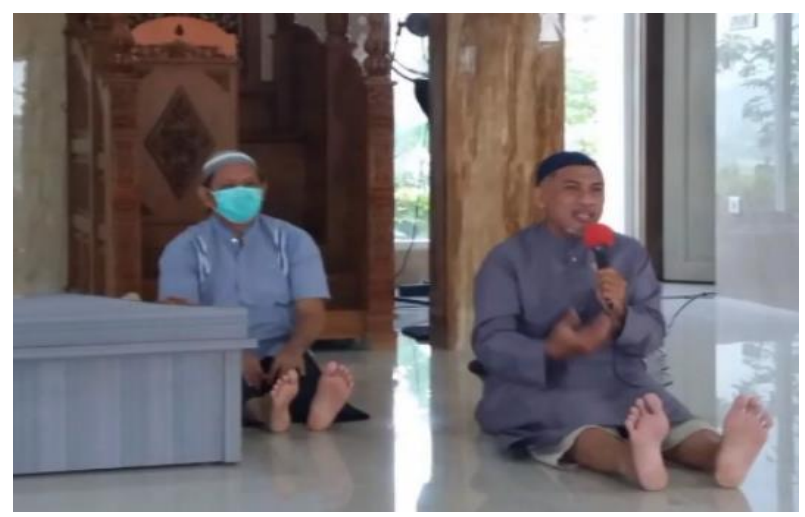

Gambar 3.1 Persiapan senam kaki diabetik dengan posisi duduk di lantai

ii. Dengan tumıt yang altetakkan aılantaı, jarı-jarı kedua kaki diluruskan kedepan dan lalu dibengkokkan kembali kebelakang 10 kali.
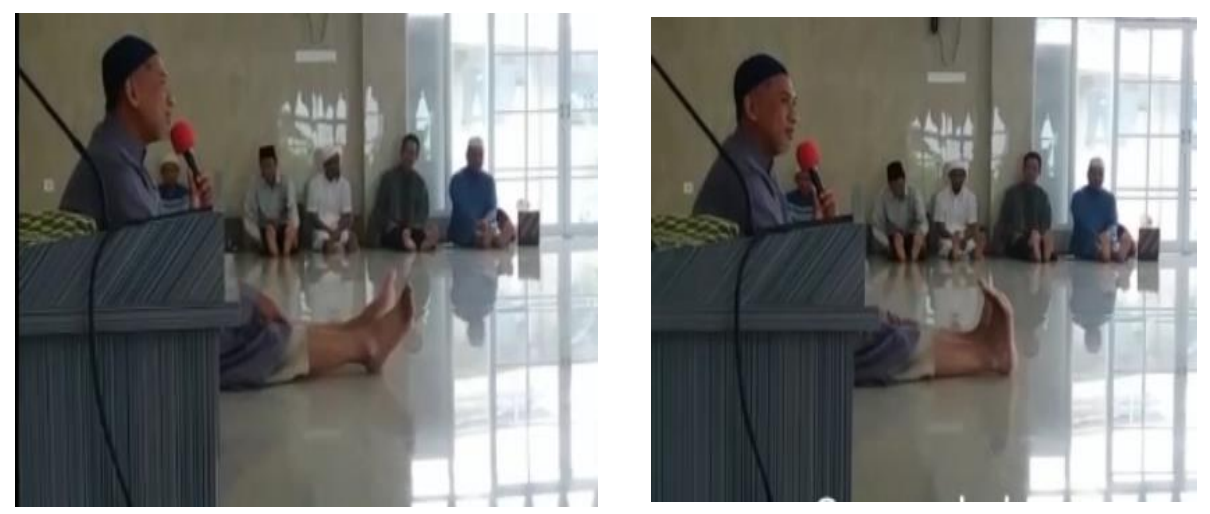

Gambar 3.2 Gerakan kaki lurus Gambar 3.3 Gerakan telapak kaki ke belakang 

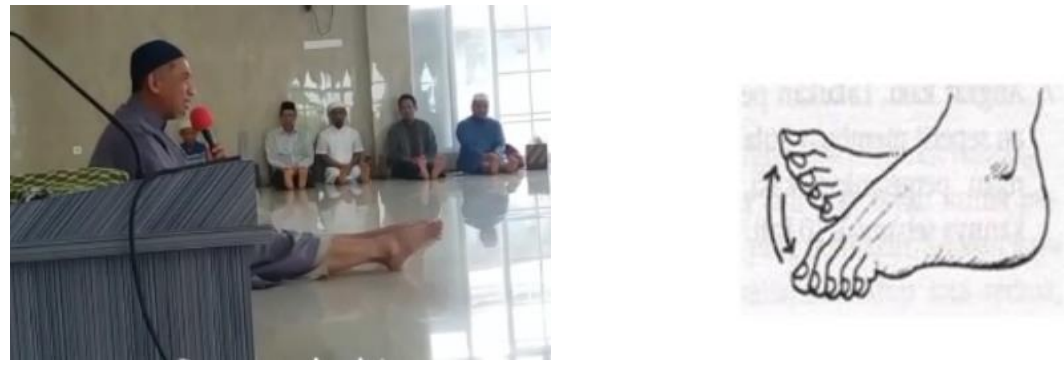

Gambar 3.4 Gerakan pergelangan kaki dan telapak kaki lurus ke arah depan

iii. Tumit kaki diletakkan di lantai. Kemudian bagian ujung jari kaki diangkat ke atas (jika duduk di kursi) atau luruskan telapak kaki dan buat gerakan memutar pada pergelangan kaki sebanyak 10 kali.
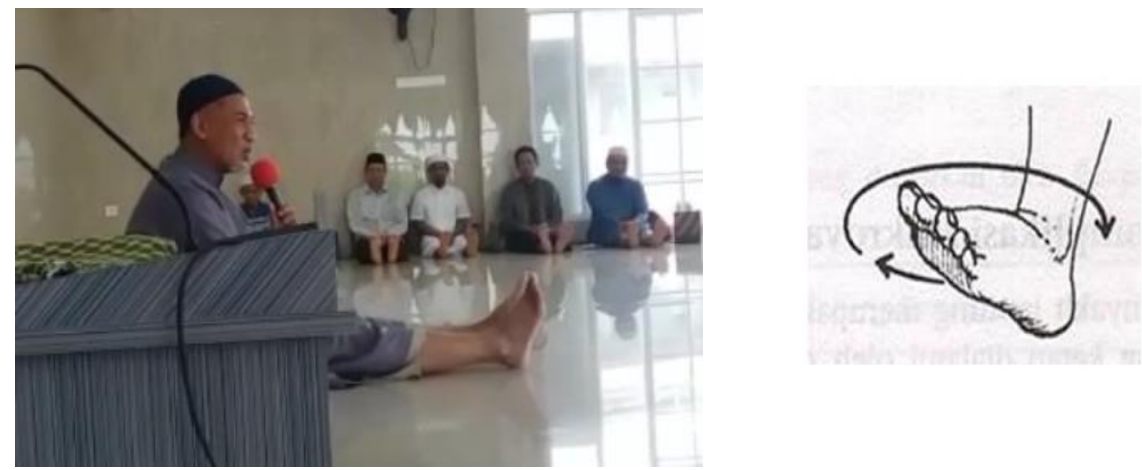

Gambar 3.5 Gerakan pergelangan kaki dan telapak rotasi ke luar dan ke dalam

iv. Kemudian angkat salah satu lutut kaki, dan luruskan. Lalu gerakan jari-jari kaki kedepan kemudian turunkan kembali secara bergantian. Ulangi gerakan ini sebanyak 10 kali.

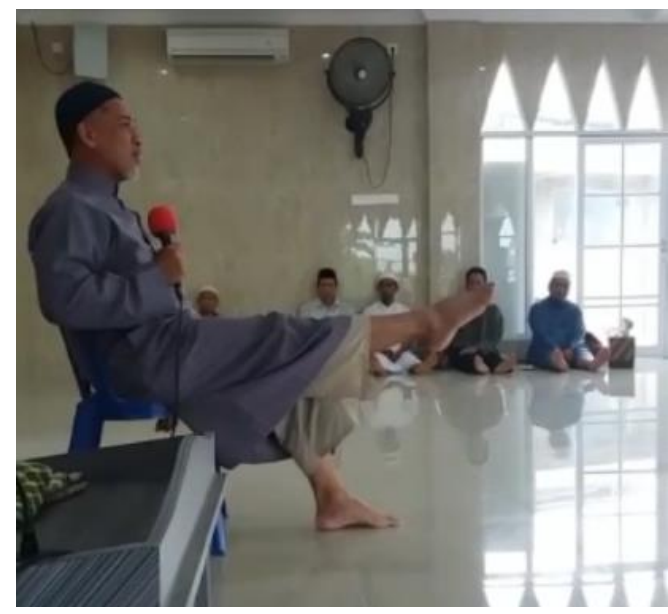

Gambar 3.6 Gerakan mengangkat kaki, meluruskan dan menurunkan ke lantai

v. Selanjutnya luruskan salah satu kaki dan angkat, lalu putar kaki pada pergelangan kaki, lakukan gerakan seperti menulis di udara dengan kaki dari angka 0 hingga 10 lakukan secara bergantian. 


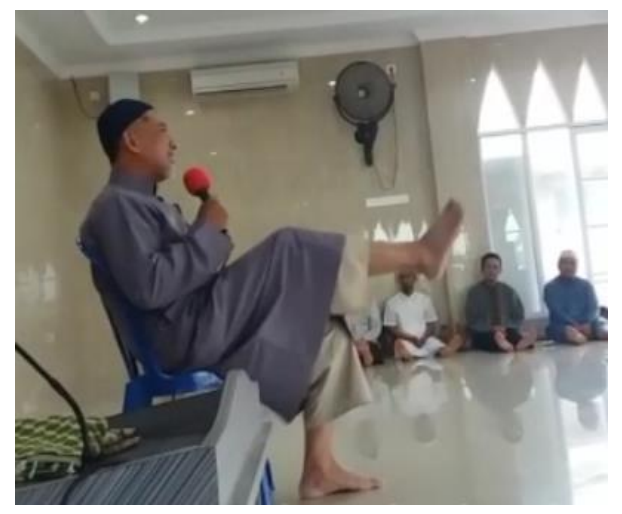

Gambar 3.7 Gerakan kaki menulis angka 1 - 10

vi. Letakkan selembar koran dilantai. Kemudian bentuk kertas koran tersebut menjadi seperti bola dengan kedua belah kaki. Lalu buka kembali bola tersebut menjadi lembaran seperti semula menggunakan kedua belah kaki. Gerakan ini dilakukan hanya sekali saja.
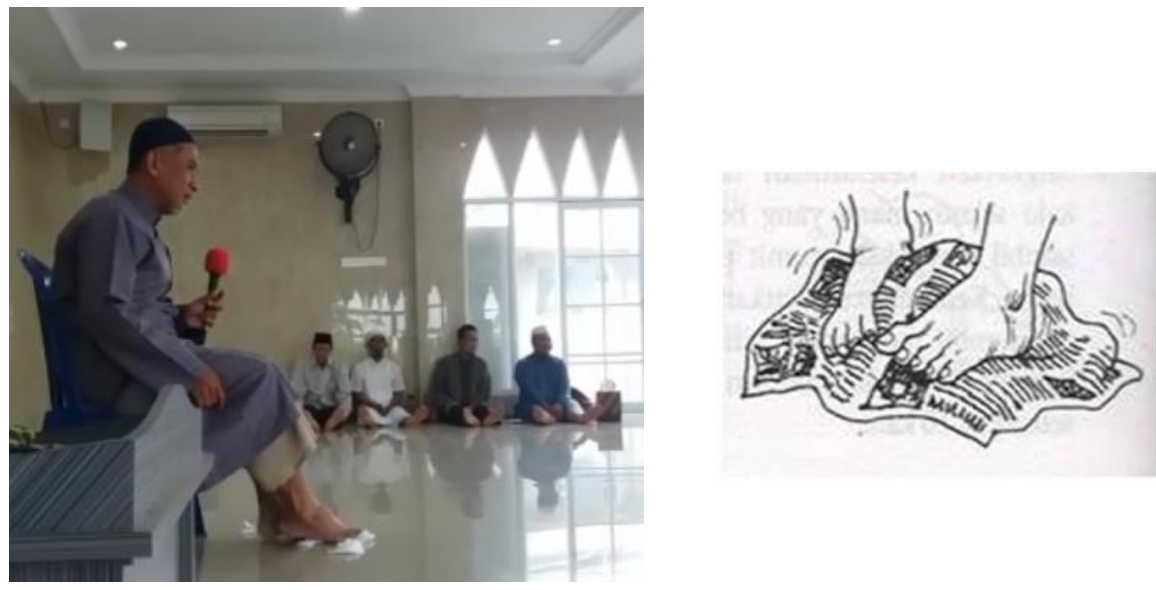

Gambar 3.8 Gerakan kaki merobek kertas/koran

vii. Kemudian robekan koran dipindahkan ke koran lainnya yang masih utuh, lalu bungkus semua sobekan-sobekan tadi dengan kedua kaki kanan dan kiri membentuk bola

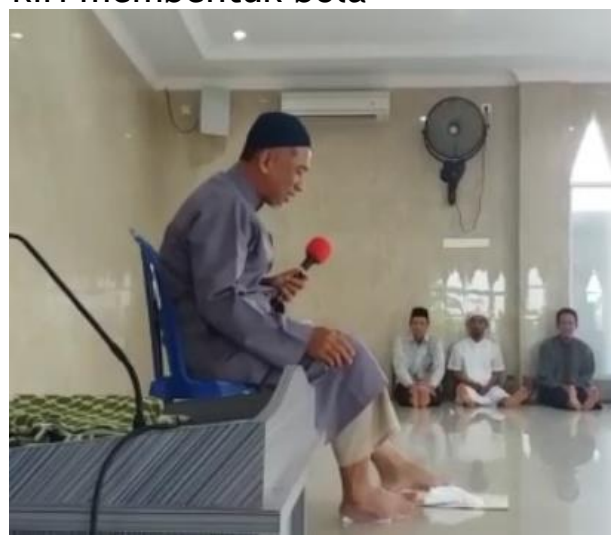

Gambar 3.9 Gerakan kaki memindahkan robekan kertas 


\section{c. Evaluasi kegiatan senam diabetik}

Evaluasi dilakukan untuk mengetahui keberhasilan dari jamaah MAS melakukan senam kaki diabetik meliputi pengukuran aspek kognitif, afektif dan psikomotor.

\section{HASIL DAN PEMBAHASAN}

Hasil pengukuran aspek kognitif :

1) Jamaah MAS mengetahui tujuan meminum jahe dan dilakukannya senam kaki

2) Jamaah Masjid Alam Semesta mengetahui manfaat meminum jahe dan senam kaki

3) Jamaah MAS mengetahui indikasi dan kontraindikasi senam kaki

4) Jamaah MAS mengetahui cara melaksanakan senam kaki.

Hasil pengukuran aspek afektif :

1) Jamaah MAS menyatakan senang mendapatkan pelatihan tentang senam kaki

2) Jamaah MAS menyatakan tertarik telah mempelajari senam kaki dan telah merasakan meminum jahe

3) Jamaah MAS menyatakan mau melaksanakannya secara rutin

4) Jamaah MAS menyadari pentingnya melaksanakan senam kaki untuk meningkatkan kebugaran dan mencegah komplikasi diabetes melitus pada kaki.

Hasil pengukuran aspek psikomotor/tindakan :

1) Jamaah MAS mampu berdiskusi perihal manfaat minum jahe dan pelaksanaan senam kaki

2) Jamaah MAS antusias, perhatian dan aktif selama kegiatan pelatihan senam kaki

3) Jamaah MAS mampu melakukan senam kaki secara mandiri.

4) Para jamaah telah mendapatkan pembagian jahe merah merk AMH super produk PT Anugrah Persada Alam Lebak Banten Indonesia yang telah memiliki ijin dari DINKES P-IRT No. 2133602010001-24 dan juga telah dibagikan brosur senam kaki. Hasil wawancara para jamaah rutin telah meminum jahe sebanyak dua bungkus perhari selama 7 hari.

\section{KESIMPULAN DAN SARAN}

Pengabdian masyarakat tentang pemberian jahe dan senam kaki memperlihatkan jamaah MAS mampu mempraktikan senam kaki diabetic dan minum jahe secara teratur sebagai upaya meningkatkan imunitas tubuh dan kebugaran. Diharapkan para jamaah masjid secara berkelanjutan minum jahe dan melakukan senam kaki diabetic secara teratur. 


\section{DAFTAR PUSTAKA}

Amalia, L., Irwan, \& Hiola, F. (2020). Analysis of Clinical Symptoms and Immune Enhancement to Prevent COVID-19 Disease. JAMBURA JOURNAL of Health Sciences and Research, 2(2), 71-76.

Asep Shodiqin, Rohmanur Aziz, Ratna Dewi, P. D. F. (2019). Model pemberdayaan jamaah masjid menghadapi dampak COVID 19. Digilib.uinsgd.ac.id, Vol. 2019, p. 2019.

Biro kerjasama hukum dan humas LIPPI. (2020). Meluruskan Informasi Khasiat Jahe Merah Lembaga Ilmu Pengetahuan Indonesia (p. 3). p. 3.

Flora, R., \& Purwanto, S. (2014). Pelatihan Senam Kaki Pada Penderita Diabetes Komplikasi Diabetes Pada Kaki (Diabetes Foot ). Unsri.Ac.Id, 7-15.

Kemenkes RI. (2020). Peraturan Menteri Kesehatan Republik Indonesia Nomor 9 Tahun 2020 Tentang Pedoman Pembatasan Sosial Berskala Besar Dalam Rangka Percepatan Penanganan Corona Virus Disease 2019 (Covid-19). Kementerian Kesehatan RI, 28. Retrieved from http://hukor.kemkes.go.id/uploads/produk_hukum/PMK_No_9_Th_2020 _ttg_Pedoman_Pembatasan_Sosial_Berskala_Besar_Dalam_Penanganan_C OVID-19.pdf

Kementerian Kesehatan Republik Indonesia. (2020). Protokol kesehatan bagi masyarakat di tempat dan fasilitas umum dalam rangka pencegahan dan pengendalian corona virus disease 2019 (covid-19). Peraturan Menteri Kesehatan Republik Indonesia, Nomor 9(Pedoman Pembatasan Sosial Berskala Besar dalam Rangka Percepatan Penanganan Corona Virus Dlsease 2019 (COVID-19)), 2-6. Retrieved from http: / / jurnalrespirologi.org/index.php/jri/article/view/101

KementrianKesehatanRI. (2020). Pedoman kesiapan menghadapi COVID-19. 0115.

Mangiwa, I., Mario E. Katuk, \& Lando Sumarauw. (2017). Pengaruh Senam Kaki Diabetes Terhadap Nilai Ankle Brachial Index Pada Pasien Diabetes Melitus. eJournal Keperawatan, 5.

P2PTM Kemenkes RI. (2019). Senam Kaki Diabetes. Kesehataan, p. 1. Retrieved from http://p2ptm.kemkes.go.id/infographic-p2ptm/penyakit-diabetesmelitus/perbaiki-sirkulasi-darah-dengan-senam-kaki-diabetes

Prativi, G. O., \& Artikel, I. (2013). Pengaruh Aktivitas Olahraga Terhadap Kebugaran Jasmani. JSSF (Journal of Sport Science and Fitness), 2(3), 3236.

Saputri, G. Z., Dania, H., \& Putranti, W. (2019). Optimalisasi Pemanfaatan Jahe (Zingiber Officinale) Dan Rosella (Hibiscus Sabdarifa) Sebagai Minuman Kesehatan Di Madrasah Muallimin Muhammadiyah Yogyakarta. Jurnal Pemberdayaan: Publikasi Hasil Pengabdian Kepada Masyarakat, 2(2), 241. https: //doi.org/10.12928/jp.v2i2.383

Sukmana, M., Aminuddin, M., \& Nopriyanto, D. (2020). Indonesian Government Response In COVID-19 Disaster Prevention. East African Scholars Journal of Medical Sciences, 3(3), 81-86. https://doi.org/10.36349/EASMS.2020.v03i03.025

Texas Medical Association. (2020). Be Informed; Know Your Risk During Covid19. Texas Medical Association, 1. Retrieved from https://www.texmed.org/uploadedFiles/Current/2016_Public_Health/Inf ectious_Diseases/309193 Risk Assessment Chart V2_FINAL.pdf

Theopilus, Y., Yogasara, T., Theresia, C., \& Octavia, J. R. (2020). Analisis Risiko Produk Alat Pelindung Diri (APD) Pencegah Penularan COVID-19 untuk 
Pekerja Informal di Indonesia. Jurnal Rekayasa Sistem Industri, 9(2), 115134. https://doi.org/10.26593/jrsi.v9i2.4002.115-134

Thineshini Devagaran, A. D., \& Farmasi, F. (2012). Senyawa Immunomodulator Dari Tanaman. Student E-Journal, 1(1), 1-2.

Tim Kerja Kementerian Dalam Negeri. (2020). Pedoman Umum Menghadapi Pandemi Covid-19 Bagi Pemerintah Daerah: Pencegahan, Pengendalian, Diagnosis dan Manajemen. Journal of Chemical Information and Modeling. https: //doi.org/10.1017/CB09781107415324.004

WHO. (2020). Coronavirus Situation Report,Coronavirus disease 2019 ( COVID19 ). 2019(February).

Yuswanto Dyah; Sudarsono, Sudarsono, A. M. , \& Sudarsono Agustinus; Mellawati, Dyah, S. Y. (2010). Pengaruh pemberian ekstrak zat pedas rimpang jahe emprit yang disari dengan etanol $70 \%$ terhadap fagositosis makrofag pada mencit jantan yang diinfeksi dengan listeria monocytogenes. Majalah Obat Tradisional, 15(Vol 15, No 3 (2010)), 112-120. Retrieved from http://journal.ugm.ac.id/TradMedJ/article/view/8135 